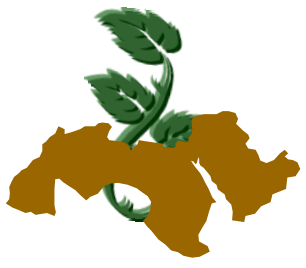

Arab Univ.

\title{
THE USE OF CITRUS FRUITS IN THE MANUFACTURE OF FLAVOURED KARISH CHEESE
}

\author{
Lamiaa F. El-Nawasany; Hanaa S.A. Sakr and Elham A. Aboel-Enin \\ Animal Production Research Institute, Agricultural Research Center, \\ Min. of Agric., Giza, Egypt
}

Keywords: Citrus fruits, Karish cheese

\begin{abstract}
Karish cheese was made by fermentation of skim milk with yoghurt starter culture $(Y)$ or by direct acidification with concentrated juice from orange $(\mathrm{O})$, grapefruit $(\mathrm{G})$ or lemon $(\mathrm{L})$. In a combination of fermentation and direct acidification, the different juices were used to give the treatments of YO, YG and YL. The highest yield (29.17\%) of the fresh cheese was recorded from $\mathrm{YL}$ treatment. This was followed by values of 27.93, 27.51 and $26.13 \%$ from $\mathrm{L}, \mathrm{YO}$, and $\mathrm{O}$ treatments in order, whereas cheese from $Y$ had the lowest yield being $21.26 \%$. Such yield values were accompanied by the corresponding vitamin $C$ contents of $6.5,7.33$, $6.35,7.50$ and $0.33 \mathrm{mg} / 100 \mathrm{~g}$, respectively. The use of different juices gave more acidic fresh cheese than cheese made using $Y$ with them or $Y$ alone which caused the lowest acidity content. The rheological properties of the fresh cheese including hardness, cohesiveness, springiness, gumminess and adhesiveness were also affected by the applied treatments. During storage of all cheese samples in the refrigerator, TS, acidity, total protein, SN/TN and FRI gradually increased with different rates, whereas only vitamin $C$ content decreased. Evaluation of the organolptic properties revealed that the use of orange or lemon juice with yoghurt starter gave the best quality of fresh cheese with the higher scores for body and texture as well as the flavour of the cheese.
\end{abstract}

\section{INTRODUCTION}

(Received 14 June, 2015)

(Accepted 1 July, 2015)
Cheese is an important part of the diet consumed in Egypt. Karish cheese is one of the most popular local types of fresh soft cheeses. Such popularity and the increasing demand for it by Egyptian consumers are mainly attributed to its high protein and low fat contents, good nutritional value in general and low price. Good digestibility and health benefits of Karish cheese should be taken into consideration in this respect. This type of cheese is more suitable for people who are suffering from certain diseases like hypertension, coronary heart disease and cardiovascular diseases in general.

However, it is well known today that food choices are driven by three needs: convenience, taste and health via nutrition value. In fact, health is the most important driver of food industry worldwide. So, functional foods are products of interest to many people due to changing of their dietary habits. However, as early as 1994 much attention has been focused on the activity of the natural antioxidants present in fruits and vegetables because potentially these components may reduce the level of oxidative stress (Thomas, 1994). On the other hand, several epidemiological studies suggest that a high intake of food rich in natural antioxidants increases the antioxidant capacity of the plasma and reduces the risk of some. Such properties are attributed to a variety of constituents including vitamins, minerals, fibers and numerous phytochemicals like flavenoids which are present in marked quantities in citrus fruits (Benavente-Garcia and Castillo, 2008; Su et al 2008; Rohman et al 2010). In this respect, Abd-Elhamid (2011) manu- 
factured functional Karish cheese using leaves extract as a source for natural antioxidant. Results of the sensory evaluation indicated that addition of $225 \mu \mathrm{g}$ phenolic compounds $/ 100 \mathrm{~g}$ cheese was the maximum limit to be added without adverse effect on sensory properties and shelf life of the product.

The present work aimed to use some citrus fruits like orange, grapefruit and lemon as good sources for some important nutrients, antioxidants and flavouring agents. The multifaceted biological roles of vitamin $C$ and its significance in human health (Iqbal et al 2004; Kuo, 2013) were strongly taken into consideration to improve health benefits of Karish cheese.

\section{MATERIALS AND METHODS}

\section{Materials}

Fresh cow's and buffalo's milk used in the present study were collected from the herds of Sakha and Mehalet Moussa Experimental Stations in order, Animal Production Research Institute, Ministry of Agriculture. Skim milk was prepared using cream separator.

Orange, grapefruit and lemon were obtained from the local market and used to prepare the juices. Concentration of the prepared juices was done at $48^{\circ} \mathrm{C}$ using the rotary evaporator under vacuum. The concentrates contained TS values of 17.77 , 16.09 and $16.16 \%$ for orange, grapefruit and lemon juices, respectively.

Yoghurt starter culture consisting of Streptococcus thermophilus and Lactobacillus delbrueckii subsp. bulgaricus (1:1) was obtained from CHRHansen Lab. (Denmark) and used for Karish cheese making. In this respect, the prepared mixed skim milk (buffalo's : cow's, 1:1) was heat treated at $90^{\circ} \mathrm{C}$ for $10 \mathrm{~min}$, then cooled to $60^{\circ} \mathrm{C}$ to be ready for the gradual addition of the concentrated juices to $\mathrm{pH} 4.6$ or 5.3. In case of reaching $\mathrm{pH} 5.3$, the active yoghurt starter was added at the rate of $1.5 \%$ from the original weight of milk to complete coagulation and to give $Y O, Y G$ and $Y L$ treatments when concentrates of orange, grapefruit and lemon juices, respectively. Treatment of $O, G$ and $L$ represented using orange, grapefruit and lemon juices were used, respectively to reach $\mathrm{pH}$ 4.6. The control Karish cheese was made using yoghurt starter only after cooling the heated skim milk to $42^{\circ} \mathrm{C}$ which was the applied temperature for all treatments containing yoghurt starter.

The traditional steps of making Karish cheese were followed (Abd El-khabir et al 2007) whereas the resultant cheese was packed in polyethylene pouches and kept in refrigerator for 30 days. Three replicates were carried out from each treatment.

The yield of fresh cheese was calculated. In addition, all cheese samples were analysed during storage period for their chemical and organoleptic properties, whereas only fresh cheese was analysed for some rheological attributes.

Cheese samples were analysed when fresh and after 10, 20 and 30 days of storage in the refrigerates for total solids (TS), acidity, total nitrogen (TN) and soluble nitrogen (SN) according to Ling (1963), vitamin $C$ content was determined as given in the AOAC (2000). Formol ripening index was also determined according Tawab and Hofi (1966).

Cheese samples for texture profile analysis (TPA) were obtained from the middle of the whole cheese block. Cheese cubes $(20 \times 20 \times 20 \mathrm{~mm})$ were placed in plastic cups, sealed (to prevent dehydration) and tempered to $12 \pm 0.5^{\circ} \mathrm{C}$ prior to analysis. A two-bite penetration test was performed using the texture analyzer (TA 1000, CNS-farnell, England) with the TA 17 probe (30 and $25 \mathrm{~mm}$ diameter) and operated at a cross head speed of 1 $\mathrm{mms}^{-1}$ and pentration distance of $10 \mathrm{~mm}$. Hardness, cohesiveness, springiness, gumminess and adhesiveness were evaluated in triplicate. All cheese samples were organopletically evaluated according to Kebary et al (2010).

Statistical analysis of variance and Duncan's test as well as average and standard error (SE) were carried out using SPSS computer program (SPSS, 1999).

\section{RESULTS AND DISCUSSION}

Cheese yield (Table 1) was significantly affected by the applied treatments. The control cheese had the lowest yield (21.26\%) whereas cheese from $\mathrm{YL}$ treatment had the highest values of $29.17 \%$. This maximum value was followed by those from treatments of $\mathrm{L}, \mathrm{YO}$ and $\mathrm{O}$ which gave yield values of $27.93,27.51$ and $26.13 \%$, respectively. Cheese made from grapefruit juice had the minimum yield $(22.33 \%)$ whereas higher value (24.15\%) was recorded when this juice was used with yoghurt starter (YG treatment).

The attained results suggest that using lemon juice alone or with yoghurt starter significantly increased the yield of Karish cheese. This was followed by orange juice and grapefruit juice. In all 


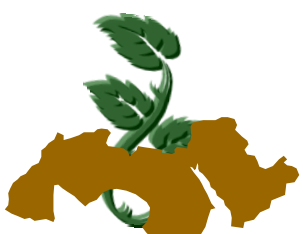

Arab Univ.

J. Agric. Sci., Ain Shams Univ., Cairo, 23(2), 563-570, 2015

Table 1. Yield of fresh Karish cheese made from milk treated with yoghurt starter and different concentrated juices (Mean \pm SE of 3 replicates) ${ }^{*}$

\begin{tabular}{|c|c|c|c|c|c|c|c|}
\hline & \multicolumn{7}{|c|}{ Treatments $^{*}$} \\
\cline { 2 - 8 } & Control $^{\star \star}$ & YO & O & YG & G & YL & L \\
\hline \multirow{2}{*}{ Yield, \% } & $21.26 \pm$ & $27.51 \pm$ & $26.13 \pm$ & $24.15 \pm$ & $22.33 \pm$ & $29.17 \pm$ & $27.93 \pm$ \\
& $0.03^{\dagger}$ & $0.09^{\mathrm{b}}$ & $0.02^{\mathrm{c}}$ & $0.02^{\mathrm{d}}$ & $0.02^{\mathrm{e}}$ & $0.008^{\mathrm{a}}$ & $0.01^{\mathrm{ab}}$ \\
\hline
\end{tabular}

* Means with unlike superscripts are significantly different $(p<0.05)$

** Control = cheese made using yoghurt starter only $(\mathrm{Y})$

$\mathrm{YO}=$ Cheese made with yoghurt starter + orange juice

$\mathrm{O}=$ Cheese made with orange juice only

$Y G=$ Cheese made with yoghurt starter + grapefruit juice

$G \quad=$ Cheese made with grapefruit juice only

$\mathrm{YL}=$ Cheese made with yoghurt starter + lemon juice

$\mathrm{L} \quad=$ Cheese made with lemon juice only

cases, combination of juice with yoghurt starter for acidification of skim milk significantly increased the yield. Such increase in the yield due to the use of different juice could be due to the TS content of the concentrated juices that were 17.77, 16.09 and $16.16 \%$ for the $\mathrm{O}, \mathrm{G}$ and $\mathrm{L}$ juices, respectively. These data were not tabulated but only determined to explain their expected impact on the yield of cheese. However, the correlation between coagulation properties of milk and cheese yielding capacity and cheese composition were the aim of some studies. Ng-Kwai-Hang et al (1989) mentioned that partial correlation coefficients between coagulating properties and cheese yield, cheese composition and milk components in whey were found. Yield of fresh soft cheese was greatly affected by applying the direct acidification (GDLtreatments) alone or with rennet in making cheese (Naeim et al 2003).

The changes of chemical composition of cheese from different treatments during storage are shown in Tables ( 2 and 3 ). It seems from TS contents (Table 2) that the values were positive correlated with the prementioned yield of the fresh cheese since the higher TS content was the main factor for increasing the yield of fresh cheese. However, TS content of fresh cheese followed nearly the same order of the yield. The maximum TS (34.22\%) was for YL-treated fresh cheese, whereas the minimum (31.81\%) for G-treated fresh cheese. It seems from the TS values that the use of yoghurt starter with any given juice significantly increased the TS content of the fresh cheese, since TS of fresh cheese from treatments of $Y O$; $Y G$ and $Y L$ had higher TS than the corresponding $O, G$ and $L$ treatments. Such increase of TS could be explained on the basis of richness of the concentrated juices with TS as previously prementioned in the yield section of Karish cheese.

The gradual increase of TS during storage the treated and untreated cheese samples were recorded in Table (2) and could be due to the corresponding loss in moisture. Such loss agrees with the results given by Kebary et al (1997); El-Sonbaty (2009) and Kebary et al (2010).

Concerning vitamin C content, Table (2) shows that the use of any juices in making cheese significantly increased vitamin $\mathrm{C}$ content in the resultant fresh cheese. The control fresh cheese had the lowest value $(p<0.05)$ of $0.33 \mathrm{mg} / 100 \mathrm{~g}$ whereas the fresh cheese from $O, L$ and $G$ treatments had higher vitamin $\mathrm{C}$ when compared with $\mathrm{YL}, \mathrm{YO}$ and $Y G$, respectively. This suggests that using any prementioned juice alone significantly increased the vitamin $\mathrm{C}$ content in cheese. Determination of vitamin $\mathrm{C}$ in the prepared concentrated juices (untabulated data) revealed that the $O, G$ and $L$ juices contained vitamin $\mathrm{C}(\mathrm{mg} / 100 \mathrm{~g})$ as 37.00 , 34.67 and 47.67 . This gives an explanation of the 
caused increase of vitamin $\mathrm{C}$ with different levels in the prepared Karish cheese.

A gradual decrease in vitamin $\mathrm{C}$ - but not identical - was recorded during cold storage of cheese to reach the values of $0.33,5.33,6.16,4.66,4.83$,

Table 2. Total solids (TS), vitamin $C$ and acidity of Karish cheese when fresh and during the cold storage as affected by the applied treatments (Mean \pm SE of 3 replicates)

\begin{tabular}{|c|c|c|c|c|c|c|c|}
\hline & \multicolumn{7}{|c|}{ Treatments $^{*}$} \\
\hline & Control & YO & $\mathbf{0}$ & YG & G & YL & $\mathbf{L}^{* *}$ \\
\hline $\begin{array}{l}\text { Storage } \\
\text { period (d) }\end{array}$ & \multicolumn{7}{|c|}{ Total solids (\%) } \\
\hline 0 & $33.34 \pm 0.66^{\mathrm{cC}}$ & $34.18 \pm 0.03^{\mathrm{dA}}$ & $33.84 \pm 0.05^{\mathrm{dB}}$ & $32.48 \pm 0.03^{\mathrm{dD}}$ & $31.81 \pm 0.02^{\mathrm{dE}}$ & $34.22 \pm 0.06^{\mathrm{dA}}$ & $33.91 \pm 0.05^{\mathrm{dB}}$ \\
\hline 10 & $35.51 \pm 0.23^{\mathrm{bc}}$ & $35.96 \pm 0.02^{\mathrm{cA}}$ & $34.27 \pm 0.18^{\mathrm{cD}}$ & $33.70 \pm 0.05^{\mathrm{cE}}$ & $32.19 \pm 0.01^{\mathrm{cF}}$ & $36.45 \pm 0.03^{\mathrm{cA}}$ & $34.60 \pm 0.04^{\mathrm{CD}}$ \\
\hline 20 & $36.55 \pm 0.02^{\mathrm{aB}}$ & $36.91 \pm 0.01^{\mathrm{bA}}$ & $35.28 \pm 0.07^{\mathrm{bD}}$ & $34.82 \pm 0.05^{\mathrm{bE}}$ & $33.86 \pm 0.03^{\mathrm{bF}}$ & $36.96 \pm 0.04^{\mathrm{bA}}$ & $35.54 \pm 0.06^{\mathrm{bC}}$ \\
\hline \multirow[t]{2}{*}{30} & $36.98 \pm 0.03^{\mathrm{aA}}$ & $37.14 \pm 0.11^{\mathrm{aA}}$ & $35.88 \pm 0.06^{\mathrm{aC}}$ & $36.23 \pm 0.13^{\mathrm{aB}}$ & $34.39 \pm 0.01^{\mathrm{aD}}$ & $37.25 \pm 0.09^{\mathrm{aA}}$ & $35.98 \pm 0.01^{\mathrm{aC}}$ \\
\hline & \multicolumn{7}{|c|}{ Vitamin C $(\mathrm{mg} / 100 \mathrm{~g})$} \\
\hline 0 & $0.33 \pm 0.16^{\mathrm{aD}}$ & $6.35 \pm 0.15 \mathrm{aB}$ & $7.50 \pm 0.00^{\mathrm{ac}}$ & $5.33 \pm 0.16^{\mathrm{aC}}$ & $6.33 \pm 0.16^{\mathrm{aB}}$ & $6.50 \pm 0.00^{\mathrm{aB}}$ & $7.33 \pm 0.16^{\mathrm{aA}}$ \\
\hline 10 & $0.17 \pm 0.16^{\mathrm{aD}}$ & $6.17 \pm 0.16 \mathrm{aB}$ & $7.33 \pm 0.16^{\mathrm{Aab}}$ & $5.33 \pm 0.16^{\mathrm{ac}}$ & $6.16 \pm 0.16^{\mathrm{aB}}$ & $6.33 \pm 0.16^{\mathrm{aB}}$ & $7.16 \pm 0.16^{\mathrm{aA}}$ \\
\hline 20 & $0.33 \pm 0.16^{\mathrm{aD}}$ & $5.83 \pm 0.16^{\mathrm{b} a \mathrm{~B}}$ & $7.00 \pm 0.00^{\mathrm{bA}}$ & $5.00 \pm 0.00^{\mathrm{abc}}$ & $5.83 \pm 0.16^{\mathrm{aB}}$ & $5.66 \pm 0.33^{\mathrm{bB}}$ & $6.66 \pm 0.16^{\mathrm{bA}}$ \\
\hline \multirow[t]{2}{*}{30} & $0.33 \pm 0.16^{\mathrm{aD}}$ & $5.33 \pm 0.16^{\mathrm{bB}}$ & $6.16 \pm 0.16^{\mathrm{cA}}$ & $4.66 \pm 0.16^{c \mathrm{C}}$ & $4.83 \pm 0.16^{\mathrm{bC}}$ & $5.33 \pm 0.16^{\mathrm{bB}}$ & $6.50 \pm 0.16^{\mathrm{bA}}$ \\
\hline & \multicolumn{7}{|c|}{ Acidity (\%) } \\
\hline 0 & $0.86 \pm 0.003^{\mathrm{dE}}$ & $0.92 \pm 0.006^{\mathrm{dC}}$ & $0.96 \pm 0.01^{\mathrm{dB}}$ & $0.87 \pm 0.01^{\mathrm{dE}}$ & $0.93 \pm 0.01^{\mathrm{cC}}$ & $0.95 \pm 0.01^{\mathrm{cBC}}$ & $1.06 \pm 0.01^{\mathrm{cA}}$ \\
\hline 10 & $0.94 \pm 0.003^{\mathrm{cD}}$ & $0.99 \pm 0.03^{\mathrm{CAB}}$ & $1.01 \pm 0.01^{\mathrm{cA}}$ & $0.97 \pm 0.01^{\mathrm{cBC}}$ & $0.96 \pm 0.08^{\mathrm{CBC}}$ & $0.97 \pm 0.01^{\mathrm{cBC}}$ & $1.20 \pm 0.01^{\mathrm{CA}}$ \\
\hline 20 & $1,22 \pm 0.003^{\mathrm{bA}}$ & $1.19 \pm 0.01^{\mathrm{bB}}$ & $1,14 \pm 0.01^{\mathrm{bBC}}$ & $1.12 \pm 0.01^{\mathrm{bCD}}$ & $1.09 \pm 0.08^{\mathrm{bE}}$ & $1.17 \pm 0.01^{\mathrm{bBC}}$ & $1.08 \pm 0.09^{\mathrm{bE}}$ \\
\hline 30 & $1.53 \pm 0.01^{\mathrm{aA}}$ & $1.37 \pm 0.01^{\mathrm{aBC}}$ & $1.30 \pm 0.01^{\mathrm{aCD}}$ & $1.29 \pm 0.01^{\mathrm{aD}}$ & $1.25 \pm 0.01^{\mathrm{aD}}$ & $1.44 \pm 0.05^{\mathrm{aB}}$ & $1.29 \pm 0.09^{\mathrm{aD}}$ \\
\hline
\end{tabular}

* See legend to Table (1) for details

${ }^{* *}$ Means with the same capital superscripts in the same row or with the small superscripts in the same column differed significantly $(p<0.05)$

Table 3. Protein content, SN/TN and formol ripening index (FRI) of Karish cheese when fresh and during the cold storage as affected by the applied treatments (Mean \pm SE of 3 replicates)

\begin{tabular}{|c|c|c|c|c|c|c|c|}
\hline & \multicolumn{7}{|c|}{ Treatments $^{*}$} \\
\hline & Control & YO & 0 & YG & G & YL & $\mathbf{L}$ \\
\hline $\begin{array}{l}\text { Storage } \\
\text { period (d) }\end{array}$ & \multicolumn{7}{|c|}{ Protein (\%) } \\
\hline 0 & $10.20 \pm 0.04^{d G}$ & $11.02 \pm 0.08^{\mathrm{dD}}$ & $11.13 \pm 0.02^{\mathrm{dC}}$ & $10.41 \pm 0.01^{\mathrm{dE}}$ & $10.32 \pm 0.01^{\mathrm{dF}}$ & $11.42 \pm 0.01^{\mathrm{dB}}$ & $11.51 \pm 0.01^{\mathrm{dA}}$ \\
\hline 10 & $11.82 \pm 0.01^{\mathrm{cC}}$ & $12.14 \pm 0.08^{\mathrm{CB}}$ & $11.81 \pm 0.02^{\mathrm{cC}}$ & $11.57 \pm 0.01^{\mathrm{cC}}$ & $11.41 \pm 0.01^{\mathrm{cC}}$ & $12.42 \pm 0.02^{\mathrm{cA}}$ & $12.02 \pm 0.01^{\mathrm{CB}}$ \\
\hline 20 & $12.62 \pm 0.01^{\mathrm{bB}}$ & $12.63 \pm 0.01^{\mathrm{bB}}$ & $12.02 \pm 0.01^{\mathrm{bD}}$ & $11.92 \pm 0.01^{\mathrm{bE}}$ & $11.63 \pm 0.01^{\mathrm{bF}}$ & $12.74 \pm 0.01^{\mathrm{bA}}$ & $12.41 \pm 0.01^{\mathrm{bC}}$ \\
\hline \multirow[t]{2}{*}{30} & $13.52 \pm 0 . .01^{\mathrm{aA}}$ & $13.13 \pm 0.02^{\mathrm{aC}}$ & $12.90 \pm 0.04^{\mathrm{aD}}$ & $12.25 \pm 0.02^{\mathrm{aE}}$ & $11.79 \pm 0.01^{\mathrm{aF}}$ & $13.22 \pm 0.01^{\mathrm{aD}}$ & $12.94 \pm 0.01^{\mathrm{aD}}$ \\
\hline & \multicolumn{7}{|c|}{ SN/TN (\%) } \\
\hline 0 & $15.66 \pm 0.08^{b c}$ & $16.90 \pm 0.19^{\mathrm{cAB}}$ & $14.99 \pm 0.52^{\mathrm{aC}}$ & $16.97 \pm 0.41^{\mathrm{bAB}}$ & $14.84 \pm 0.35^{\mathrm{abc}}$ & $17.16 \pm 0.66^{\mathrm{bA}}$ & $15.71 \pm 0.21^{\mathrm{aBC}}$ \\
\hline 10 & $15.61 \pm 0.26^{\mathrm{bAB}}$ & $17.27 \pm 0.43^{\mathrm{CA}}$ & $17.16 \pm 1.03^{\mathrm{aA}}$ & $15.53 \pm 0.85^{\mathrm{bAB}}$ & $14.16 \pm 1.40^{\mathrm{bB}}$ & $17.86 \pm 0.80^{\mathrm{abA}}$ & $15.96 \pm 0.61^{\mathrm{aAB}}$ \\
\hline 20 & $16.94 \pm 0.85^{\mathrm{ab} A \mathrm{~B}}$ & $18.82 \pm 0.45^{\mathrm{bA}}$ & $17.23 \pm 0.32^{\mathrm{aAB}}$ & $16.17 \pm 0.98^{\mathrm{bB}}$ & $16.63 \pm 0.63^{\mathrm{abAB}}$ & $17.93 \pm 0.93^{\mathrm{ab} A \mathrm{~B}}$ & $17.03 \pm 0.32^{\mathrm{aAB}}$ \\
\hline \multirow[t]{2}{*}{30} & $18.64 \pm 0.98^{\mathrm{aBC}}$ & $20.75 \pm 0.42^{\mathrm{aA}}$ & $16.41 \pm 0.46^{\mathrm{aD}}$ & $20.14 \pm 0.35^{\mathrm{aAB}}$ & $17.29 \pm 0.65^{\mathrm{aCD}}$ & $19.74 \pm 0.15^{\mathrm{aAB}}$ & $16.88 \pm 0.35^{\mathrm{aD}}$ \\
\hline & \multicolumn{7}{|c|}{ FRI } \\
\hline 0 & $2.05 \pm 0.01 \mathrm{dD}$ & $2.14 \pm 0.01^{\mathrm{Cd}}$ & $2.29 \pm 0.02^{\mathrm{dB}}$ & $2.07 \pm 0.01 \mathrm{dD}$ & $2.14 \pm 0.02^{\mathrm{dC}}$ & $2.25 \pm 0.01 \mathrm{~dB}$ & $2.36 \pm 0.02^{\mathrm{dA}}$ \\
\hline
\end{tabular}




\begin{tabular}{|c|c|c|c|c|c|c|c|}
\hline 10 & $2.63 \pm 0.01^{\mathrm{CB}}$ & $2.79 \pm 0.06^{\mathrm{ABC}}$ & $2,58 \pm 0.01^{\mathrm{CCD}}$ & $2.61 \pm 0.01^{\mathrm{cB}}$ & $2.59 \pm 0.03^{\mathrm{cF}}$ & $2.80 \pm 0.01^{\mathrm{CA}}$ & $2.57 \pm 0.01^{\mathrm{cE}}$ \\
20 & $2.95 \pm 0.01^{\mathrm{bB}}$ & $2.96 \pm 0.01^{\mathrm{bB}}$ & $2.79 \pm 0.01^{\mathrm{bC}}$ & $2.82 \pm 0.01^{\mathrm{bC}}$ & $2.60 \pm 0.01^{\mathrm{bE}}$ & $3.16 \pm 0.01^{\mathrm{bA}}$ & $2.75 \pm 0.03^{\mathrm{bD}}$ \\
30 & $3.36 \pm 0.01^{\mathrm{aA}}$ & $3.29 \pm 0.01^{\mathrm{aB}}$ & $3.01 \pm 0.01^{\mathrm{aC}}$ & $2.97 \pm 0.01^{\mathrm{aCD}}$ & $2.81 \pm 0.01^{\mathrm{aE}}$ & $3.31 \pm 0.01^{\mathrm{aB}}$ & $2.96 \pm 0.02^{\mathrm{aD}}$ \\
\hline
\end{tabular}

* See legend to Tables (2 and 3) for details

The acidity of cheese (Table 2) varied due to fermentation of lactose when yoghurt starter was used or due to direct acidification with different juices. The acidic nature of the prepared juices was recorded when acidity of them were determined. The acidity values were $3.43,3.60$ and $5.20 \%$ expressed as lactic acid for O, G and L juices, respectively. These values (untabulated) were accompanied with $\mathrm{pH}$ values of $2.83,2.80$ and 1.89 , respectively. Such acidic nature of juices gave the resultant cheese samples their recorded acidity.

The changes in acidity during storage were almost significant with a gradual increase reaching the maximum value at the end of storage period. However, the acidity values were $1.53,1.37,1.30$, $1.29,1.25,1.44$ and $1.29 \%$ for 30 days old Karish cheese made from the control and $Y O, O, Y G, G$, $Y L$ and $L$ treatments in order. Such increase in acidity during storage of Karish cheese was previously given by Kebary et al (1997) ; El-Sonbaty (2009) and Kebary et al (2010) and is most likely due to fermentation of residual lactose.

The results in Table (3) indicated that the total protein was the lowest in the fresh control cheese, whereas the highest values was noticed for the fresh lemon juice treated cheese with the corresponding values of 10.2 and $11.51 \%$, respectively. Protein contents of the fresh control and that made using grapefruit juice were slightly higher than $10.0 \%$.

A gradual increase in protein content of all cheese samples was recorded during storage reaching the maximum values at the end of storage period with the values of $13.52,13.13,12.90$, $12.25,11.79,13.22$ and $12.94 \%$ for the control and cheese from treatments $Y O, O, Y G, G, Y L$ and $L$, respectively. Such increase in protein could be attributed to the corresponding loss in moisture content. This agrees with the trend given by Naeim et al (2003) for GDL-treated soft cheese, whereas Kebary et al (2010) demonstrated that TN content per dry matter of Karish cheese did not change significantly as storage period proceeded.

The use of yoghurt starter and juices gave the highest SN/TN in the fresh prepared cheese (Table 3) with insignificant differences among them. The fresh cheese from YO, YG and $Y L$ treatments had the SN/TN values of $16.90,16.97$ and $17.16 \%(p>0.05)$. These values were significantly higher than the corresponding values of those from treatments of $O, G$ and $L$ as well as the value of control fresh cheese. Such values were gradually increased in most cases during the storage period, reaching the maximum values of $18.64,20.75,16.41,20.14,17.29,19.74$ and $16.88 \%$ for the control and treatments of $\mathrm{YO}, \mathrm{O}$, $Y G, G, Y L$ and $L$, respectively. This might be due to protein degradation into water soluble nitrogen and is in agreement with the trend given by Kebary et al (1997); El-Sonbaty (2009) and Kebary et al (2010).

Table (3) shows that FRI had the maximum value in L-treated fresh cheese and the minimum one in the control fresh cheese. The differences in this respect were mainly significant. The recorded values gradually increased during storage reaching the maximum values at the end of storage with the highest value (3.36) for the control cheese. This agrees with the trend given by Naeim et al (2003).

The rheological properties of the fresh cheese seem to be greatly affected by the applied treatments. Cheese from $Y G$ and $L$ treatments had the highest significant hardness, whereas the control cheese had value of $17.76 \mathrm{~g}$, which significantly higher than the values of cheese from $\mathrm{YO}, \mathrm{O}$ and $G$ treatments. Cohesiveness had the maximum value in G-treated cheese with insignificant differences with the values given for $O, Y G$ and $L$ treated cheese. The control cheese had value of 0.56 which insignificantly different from the values given for YO, O, YG and L-treated cheese.

Insignificant differences were recorded for springiness of cheese from $O, Y G$ and $G$ treatments but the recorded values were significantly higher than those given for the control and the other treated cheese samples which showed insignificant differences among them.

The fresh cheese from $L$ treatment (Table 4) had the lowest values ( $p>0.05)$ of gumminess and adhesiveness. The maximum gumminess values were given for $O, Y G$ and $Y L$-treated cheese samples with insignificant differences among them, whereas the maximum adhesiveness values were given for the control and YG-treated cheese with insignificant differences among them ( $p>0.05$ ).

Such results suggest that type of acidification had an important impact on the rheological attrib- 
utes of Karish cheese. Lemon juices had an increasing impact on cheese hardness, whereas using $\mathrm{O}$ or $\mathrm{L}$ with yoghurt starter showed decreasing effect in this respect. The opposite was recorded when $\mathrm{G}$ was used with yoghurt starter. The rest

Table 4. The rheological properties of the fresh Karish cheese as affected by using yoghurt starter or different juices as coagulants in cheese making (Mean \pm SE of 3 replicates)

\begin{tabular}{|c|c|c|c|c|c|c|c|}
\hline \multirow{2}{*}{ Property } & \multicolumn{7}{|c|}{ Treatments $^{*}$} \\
\cline { 2 - 7 } & Control & YO & O & YG & G & YL & L \\
\hline Hardness $(\mathrm{g})$ & $17.76 \pm 36.2^{\mathrm{c}}$ & $12.17 \pm 7.5^{\mathrm{d}}$ & $17.00 \pm 7.5^{\mathrm{c}}$ & $38.95 \pm 1.5^{\mathrm{a}}$ & $16.38 \pm 1.9^{\mathrm{c}}$ & $23.08 \pm 8.9^{\mathrm{b}}$ & $36.70 \pm 6.0^{\mathrm{a}}$ \\
\hline $\begin{array}{c}\text { Cohesiveness } \\
\text { (ratio) }\end{array}$ & $0.56 \pm 0.19^{\mathrm{b}}$ & $0.59 \pm 0.05^{\mathrm{b}}$ & $0.67 \pm 0.00^{\mathrm{ab}}$ & $0.65 \pm 0.05^{\mathrm{ab}}$ & $0.77 \pm 0.00^{\mathrm{a}}$ & $0.47 \pm 0.01^{\mathrm{c}}$ & $0.65 \pm 0.05^{\mathrm{b}}$ \\
\hline Springiness $(\mathrm{mm})$ & $6.05 \pm 0.02^{\mathrm{b}}$ & $6.30 \pm 0.01^{\mathrm{b}}$ & $9.22 \pm 0.03^{\mathrm{a}}$ & $9.65 \pm 0.01^{\mathrm{a}}$ & $9.58 \pm 0.06^{\mathrm{a}}$ & $6.06 \pm 0.01^{\mathrm{b}}$ & $4.88 \pm 0.05^{\mathrm{b}}$ \\
\hline Gumminess $\left(\mathrm{g}^{\mathrm{s}-1}\right)$ & $71.99 \pm 0.19^{\mathrm{b}}$ & $74.13 \pm 9.02^{\mathrm{b}}$ & $116.09 \pm 1.34^{\mathrm{a}}$ & $109.58 \pm 0.31^{\mathrm{a}}$ & $42.21 \pm 0.18^{\mathrm{c}}$ & $110.33 \pm 0.34^{\mathrm{a}}$ & $40.48 \pm 0.05^{\mathrm{c}}$ \\
\hline Adhesiveness $\left(\mathrm{g}^{\mathrm{s}-1}\right)$ & $93.00 \pm 1.6^{\mathrm{a}}$ & $39.50 \pm 0.5^{\mathrm{d}}$ & $56.00 \pm 1.0^{\mathrm{c}}$ & $86.50 \pm 2.0^{\mathrm{a}}$ & $36.00 \pm 1.0^{\mathrm{b}}$ & $65.00 \pm 0.5^{\mathrm{b}}$ & $33.50 \pm 0.05^{\mathrm{d}}$ \\
\hline
\end{tabular}

* See legend to Table (1) for details degree of impact varied also depending on the applied treatment and the rheological property. No data are available from the literature for composition. The available trials to improve the rheological properties of Karish cheese were made by Hassan et al (2004) and Ahmed et al (2005). They used expolysaccharide-producing bacteria in this respect.

The sensory evaluation was given in Table (5). for general appearance (9.60 points out of 10), whereas the use of $G$ or $Y G$ significantly decreased the scores given for this property. Control cheese had a value of 8.66 out of 10 points suggesting that most of the panelists preferred cheese without orange or grapefruit juices.

Again cheese from YL treatment was the best among all cheese samples evaluated for body and texture, since it ranked the highest score for such Cheese from $Y L$ treatment had the maximum score rheological properties were less affected by the applied treatments since different trends were recorded due to the applied treatments and the between such score and the score given for YOcheese. Only treatments $O$ and $G$ decreased significantly the scores given for body and texture of the resultant cheese.

More than 56 points out of 60 were given for flavour of cheese made from $Y O$ and $Y L$ treatments. The corresponding scores were significantly lower when $\mathrm{O}$ or $\mathrm{L}$ treatments were used without adding yoghurt starter. However, the differences were insignificant $(p>0.05)$ between the scores given for flavour of control cheese and cheese made using $\mathrm{O}, \mathrm{G}$ or $\mathrm{L}$ treatments.

The present results suggest possibility of using yoghurt starter and orange or lemon juice in making a good quality flavoured Karish cheese. Richness of such cheese with vitamin $C$ should be strongly taken into consideration in this respect.

Table 5. The organoleptic scoring of the fresh Karish cheese made from skim treated with different concentrated juices individually or in a combination with yoghurt starter (Mean \pm SE of 15 panelists)

\begin{tabular}{|c|c|c|c|c|c|c|c|}
\hline \multirow{2}{*}{ Property } & \multicolumn{7}{|c|}{ Treatments $^{*}$} \\
\cline { 2 - 8 } & Control & YO & O & YG & G & YL & L \\
\hline $\begin{array}{c}\text { General appearance } \\
(10 \text { points })\end{array}$ & $8.66 \pm 0.33^{\mathrm{ab}}$ & $8.33 \pm 0.30^{\mathrm{bc}}$ & $8.00 \pm 0.57^{\mathrm{bc}}$ & $7.66 \pm 0.33^{\mathrm{bc}}$ & $7.33 \pm 0.33^{\mathrm{c}}$ & $9.66 \pm 0.33^{\mathrm{a}}$ & $8.66 \pm 0.33^{\mathrm{ab}}$ \\
\hline $\begin{array}{c}\text { Boy and texture } \\
(30 \text { points })\end{array}$ & $25.33 \pm 0.33^{\mathrm{bc}}$ & $27.00 \pm 0.33^{\mathrm{ab}}$ & $23.66 \pm 0.33^{\mathrm{cd}}$ & $25.66 \pm 0.33^{\mathrm{bc}}$ & $22.33 \pm 1.40^{\mathrm{d}}$ & $28.33 \pm 0.33^{\mathrm{a}}$ & $25.33 \pm 1.33^{\mathrm{bc}}$ \\
\hline
\end{tabular}




\begin{tabular}{|c|r|r|r|r|r|r|c|}
\hline $\begin{array}{c}\text { Flavour } \\
(60 \text { points })\end{array}$ & $53.66 \pm 0.33^{\mathrm{b}}$ & $56.66 \pm 0.33^{\mathrm{a}}$ & $54.33 \pm 0.66^{\mathrm{b}}$ & $55.33 \pm 0.66^{\mathrm{ab}}$ & $54.00 \pm 1.00^{\mathrm{b}}$ & $56.33 \pm 0.33^{\mathrm{a}}$ & $53.66 \pm 0.66^{\mathrm{b}}$ \\
\hline
\end{tabular}

* See legend to Table (1) for details

\section{REFERANCES}

Abd-Elhamid, A.M. 2011. Production of functional Karish cheese: Effect of natural antioxidant from guava (Psidium guajava) leaves extract. Egyptian J. Dairy Sci. 39: 101-110.

Abd El-khabir, A.A., Moussa, M.A.M. and Abd El-Malek, F.A. 2007. Effect of carbon dioxide treatment on the shelf-life of Karish cheese. Annals Agric. Sci., 52: 429-438.

Ahmed, N.H., El-Soda, M., Hassan, A.N. and Frank, J. 2005. Improving the textural properties of an acid-coagulated (Karish cheese) using exopolysaccharide producing cultures. LWT, 38: 843-847.

AOAC, 2000. Association Official Analysis. $17^{\text {th }}$ ed., Washington DC, USA.

Benavente-Garcia, O. and Castillo, J. 2008. Update on uses and properties of citrus flavonoids: new finding in anticancer, cardiovascular and anti-inflammatory activity. J. Agric. Food Chem., 56: 6185-6205.

El-Sonbaty, A.H. 2009. Quality development of Karish cheese during ripening with special reference to biogenic amines. J. Agric. Res. Kafr El-Shiekh Univ., 35: 594-608.

Hassan, A.N., Corredig, M., Frank, J.F. and El-Soda, M. 2004. Microstructure and rheology of an acid-coagulated cheese (Karish) made with an exopolysaccharide -producing Streptococcus theromophilus and its exopolysaccharide- non producing genetic variant. J. Dairy Res. 71: 116-120.

lqbal, Kh., Khan, A. and Khatak, M.M.A.Kh. 2004. Biological significance of ascorbic acid (vitamin C) in human health - A Review. Pakistan J. Nutrition 3: 5-13.

Kebary, K.M.K., Salem, O.M., Hamed, A.I. and El-Sisi, A.S. 1997. Flavour enhancement of direct acidified Karish cheese using attenuated lactic acid bacteria. Food Res. Int. 30: 265272.

Kebary, K.M.K., Salem, O.M., Rady, A.H., El-Sonbaty, A.M., Badran, I.I. and Sallam, E.M. 2010. Improving quality of Karish cheese by gamma irradiation. Minufiya J. Agric. Res., 35: 529-542.

Kuo, S.M. 2013. The multifaceted biological roles of vitamin C.J. Nutr. Food Sci., 3:5 doi: 10.4172/2155-9600.1000231.

Ling, E.R. 1963. A Text Book of Dairy Chemistry. Vol. 2, Practical. $3^{\text {rd }}$ ed., Chapman and Hall, London, UK, pp. 79-85.

Naeim, M.A., Al-Ahwall, R.I.H. and Mehanna, N.M. 2003. Composition and quality of soft cheese made from GDL-treated milk. J. Agric. Res. Tanta Univ., 29: 445-454.

Ng-Kwai-Hang, K.F., Politis, I., Cu, R.I. and Marziali, A.S. 1989. Correlation between coagulation properties of milk and cheese yielding capacity and cheese composition. Can. Inst. Food Sci. Techol. J. 22: 291-302.

Rohman, A., Riyanto, S., Yuniarti, N., Saputra, W.R., Utami, R. and Mulatsi, W. 2010. Antioxidant activity, total phenolic and total flavonoid of extracts and fractions of red fruits (Pandamus conoideus Lam). Int. Food Res. J. 17: 97106.

SPSS 1999. Statistical Package for Social Science. SPSS Inc., Chicago, USA.

Su, M.S., Shyu, Y.T. and Chein, P.J. 2008. Antioxidant activity of citrus herbal product extracts. Food Chem. 111: 892-896.

Tawab, G.A. and Hofi, A.A. 1966. Testing cheese ripening by rapid chemical techniques. Indian J. Dairy Sci., 19: 39-41.

Thomas, J.A. 1994. Oxidative stress, oxidative defense and dietary constituents. In: Modern Nutrition in Health and Disease. $8^{\text {th }}$ ed., Lee and Febiger, Philadelphia pp. 501-512. 